\title{
The Effect of Financial Technology, Company Characteristics and Owner Characteristics on MSME Financial Decisions in Bali Province
}

\author{
Ni Nengah Era Sugiartini*, Ni Luh Putu Wiagustini** \\ * Faculty of Economics and Business, Udayana University, Bali, Indonesia \\ * Faculty of Economics and Business, Udayana University, Bali, Indonesia \\ *email correspondent:
}

DOI: 10.29322/IJSRP.10.11.2020.p10773

http://dx.doi.org/10.29322/IJSRP.10.11.2020.p10773

\begin{abstract}
This study aims to determine how the effect of financial technology, company characteristics and owner characteristics on fonancial decisions. The population of this research is the MSMEs in Bali Province with a total of 481,853 units. The number of samples in this study were 100 respondents who were determined based on the Slovin formula with a critical value of 10 percent. The sampling technique used was purposive sampling method based on MSMEs that know about Fintech lending, namely online lending and borrowing services. The method of collecting data through a questionnaire. The data analysis technique used is multiple linear regression analysis and previously carried out factor analysis to determine indicators that can represent variables seen from the highest MSA (Measure of Sampling Adequacy) value. The results of this study indicate that financial technology, company characteristics and owner characteristics have a positive effect on financial decisions.
\end{abstract}

Keywords: Financial Decisions, Financial Technology, Company Characteristics, Owner Characteristics

\section{INTRODUCTION}

$\mathrm{T}$ he problem of financing is an important aspect in determining the sustainability of the company and as a basis for making financial decisions by companies, including MSMEs. A company financial decision is a decision made by a financial manager relating to how to finance investment decisions to be made and determining the composition and source of financial (Kumar, 2012). The financial decision, according to Suad Husnan and Pudjiastuti (2015: 277), concerns the form and composition of the financial that the company will use. This decision is a financial management decision in considering and analyzing the most economical mix of sources of funds for the company to finance investment needs and operational activities. Financial decisions cover two important things, first, about where company funds are met and second, related to the analysis of the cost of capital used by the company (Wiagustini, 2014: 207). In his book, Sartono (2016: 301) states that the sources of funds are divided into time, namely short, medium and long term. According to research conducted by Nugroho (2010), these sources of financial can be grouped into two, namely internal sources of funds and external sources of funds. Internal sources of funds come from the owners themselves and external sources of funds come from outside the business owners, both formal and informal. Practically, in selecting the source of company financial according to Riyanto in Wiagustini (2014: 223-228), it is divided into three forms of analysis. First, the analysis of the approach to economic profitability and equity profitability, which is related to the use of debt, can provide higher returns than interest on the debt. The second is the analysis of the liquidity approach, which relates to whether the use of debt can cause liquidity difficulties or not. The third is cash flow analysis, namely the approach to using debt by considering the ability to pay on time. Avery et al. (1998) explained that the main and most important sources of financial for start-up companies are funds from the owner of the company and informal external loans. The study conducted by Rossi et al. (2016) found that special financial sources for small and medium enterprises are divided into two, namely internal sources and external sources. Internal sources include financial from retained earnings, asset sales and reduced inventories, while external sources include loans from short, medium and long-term creditors.

Apart from education, the gender of the business owner plays an important role in financial decisions The gender of micro and small business actors can differentiate opportunities in accessing financial. Based on the results of the continued 2016 Economic Census analysis, that the chances of male MSME owners in Bali to access financial is 1.47 times higher than that of women (BPS, 2019a). Female owners are considered to face more difficulties in accessing financial than men (Blackburn, 2013). In Sri Lanka, female owners have less access to external financial to fulfil their business (Kuruppu \& Azeez, 2016). Coleman (2000) found that women entrepreneurs prefer to avoid external financial due to a strong desire not to have obligations with others. Along with the development of information technology, other factors become important in making decisions about sources of funds for companies, especially MSMEs. The government, through the Financial Services Authority (OJK), assesses that digital financial services are a solution that can save the 
sustainability of MSMEs from difficult access to finance (Rizal, 2018). Chairman of the OJK Board of Commissioners Wimboh Santoso said that digital financial services could make it easier for people to make transactions and to obtain financing. This digital financial service is called financial technology or abbreviated as Fintech (Ahad, 2017). Based on the Bank Indonesia Financial Stability Study (2017a), Fintech is considered capable of reaching people who have not had access to finance by banks. The type of Fintech service in Indonesia that is widely used is Fintech lending, also known as Peer to Peer Lending (P2PL), which is an online loan service. Fintech lending is a financing platform that is considered capable of reaching the MSME sector as an alternative source of external financial (Ardiansyah, 2019). Fintech lending is proven to be an alternative solution in meeting short-term financing needs (Gibilaro \& Mattarocci, 2018). According to Urban's research (2019), an easy and fast process is the dominant factor for MSMEs in making loan decisions through Fintech. This fintech lending can be alternative financing with lower transaction costs because the loan process is carried out online and can reduce information asymmetry (Xiang, 2018).

The Indonesian Joint Financial Fintech Association (AFPI) has regulated in a code of conduct that the total loan cost does not exceed a flat interest rate of 0.8 per cent per day. There is also a stipulation that the total amount of fees, late fees, and all other fees is a maximum of 100 per cent of the principal value of the loan. Based on data published by the Financial Services Authority (OJK), it shows the rapid growth of Fintech lending in Indonesia. The accumulated distribution of loans nationally until January was Rp.88.37 trillion with a national accumulation of borrower accounts of 20,497,167 entities with 164 Fintech lending companies registered or licensed by OJK Regulation No. 77 of 2016 (OJK, 2020). This condition shows that the availability of Fintech lending in Indonesia can assist the government in providing financial services and loans that are broader and more efficient. Based on the results of research conducted by Huang (2020), it is stated that the development of digital financial access has a positive and significant effect on alleviating the constraints of financing for MSMEs. The same results were also found in Hakim Ghazali's (2018) research that the existence of Fintech lending has a positive effect on financing problems in Malaysia.

Fintech can be an alternative financing option that can stimulate business activities in Malaysia. In contrast to Sybirianska et al. (2018) which shows that the existence of Fintech lending has not been effectively utilized as an alternative to financing MSMEs in Ukraine. Analysis of the Ukrainian tech market found that more than 60 percent of Fintech lending platforms were launched in the past three years, but their usage has not been maximized. Seeing the importance of financial decisions and the factors that influence them, this study aims to see how the influence of Fintech, company characteristics and owner characteristics on financial decisions focused on the MSME sector in Bali Province. Based on the explanation above, the hypotheses that can be stated are:

H1: Financial technology has a positive and significant effect on financial decisions.

H2: Company characteristics have a positive and significant effect on financial decisions.

H3: Owner characteristics have a positive and significant effect on financial decisions

\section{METHODS}

This research was conducted in Bali Province by making nine areas as the focus. The areas referred to in this study are Klungkung Regency, Karangasem Regency, Jembrana Regency, Singaraja Regency, Tabanan Regency, Badung Regency, Gianyar Regency, Bangli Regency and Denpasar City. The location of this research was chosen because it saw the suitability of the topics and problems raised, namely in the MSMEs sector. The existence of MSMEs is one of the sectors driving the economy in Bali Province with a total of 481,853 MSMEs and of course it can represent research carried out related to financial decisions (BPS, 2019b).

The population in this study were 481,853 MSMES units in Bali Province. The sampling method is divided into two ways, namely probability sampling and non-probability sampling. This study uses a non-probability sampling method in determining the sample. Nonprobability sampling is a non-random sampling method that does not provide equal opportunities or opportunities for all elements or members of the population to be selected as samples. The sample size used as a respondent is determined based on population size. The samples taken in this study were 100 MSMES units which were determined using the Slovin approach. The Slovin formula used is as follows.

$n=\frac{N}{1+N e^{2}}$

This publication is licensed under Creative Commons Attribution CC BY.

http://dx.doi.org/10.29322/IJSRP.10.11.2020.p10773

WwW.ijsrp.org 
Information:

$\mathrm{n}=$ sample size

$\mathrm{N}=$ population size

$\mathrm{e}=$ error limit / critical value $(10 \%)$

The calculation of the number of samples in the study using the Slovin approach is as follows:

$$
\begin{aligned}
& n=\frac{N}{1+N e^{2}} \\
& n=\frac{481.853}{1+481.853(0,1)^{2}} \\
& n=\frac{481.853}{1+4.818,53} \\
& n=\frac{481.853}{4.819,53} \\
& \mathrm{n}=99,98(100) .
\end{aligned}
$$

The number of samples used is 100 MSMEs units, so that the population can be fully represented, the sampling is based on districts and cities in Bali Province. The data were collected using a research instrument in the form of a questionnaire that was distributed directly to the respondents. The questionnaire in this study was measured based on the respective measurement scales of each variable studied. This study uses qualitative data which will later be quantified with a measurement scale of each variable so that it can be processed using regression analysis with the help of SPSS. This study uses multiple linear regression, namely the analysis used to determine the effect of financial technology, company characteristics and owner characteristics on financial decisions Here is a form of multiple linear regression equation used in the study.

$$
\mathrm{Y}=\alpha+\beta_{1} \mathrm{X}_{1}+\beta_{2} \mathrm{X}_{2}+\beta_{3} \mathrm{X}_{3}+\mathrm{e}
$$

Information:

Y: Financial decision

$\mathrm{X} 1$ : Financial technology

$\mathrm{X} 2$ : Company characteristics

X3: Characteristics of the owner

$\alpha$ : Constant parameter

$\beta 1, \beta 2, \beta 3$, : Multiple regression coefficients

e: Another factor that affects the variable $\mathrm{Y}$

\section{RESEARCH AND DISCUSSION}

\begin{tabular}{|c|c|c|c|c|c|}
\hline \multirow[t]{2}{*}{ Model } & \multicolumn{2}{|c|}{ Unstandardized Coefficients } & \multirow{2}{*}{$\begin{array}{l}\text { Standardized } \\
\text { Coefficients } \\
\text { Beta }\end{array}$} & \multirow[b]{2}{*}{$\mathrm{t}$} & \multirow[b]{2}{*}{ Sig. } \\
\hline & B & Std. Error & & & \\
\hline (Constant) & $-0,822$ & 0,553 & & $-1,485$ & 0,141 \\
\hline Financial Technology (X1) & 0,392 & 0,154 & 0,222 & 2,539 & 0,013 \\
\hline Company Characteristics (X2) & 0,263 & 0,069 & 0,334 & 3,805 & 0,000 \\
\hline Owner's Characteristics (X3) & 0,271 & 0,056 & 0,419 & 4,819 & 0,000 \\
\hline
\end{tabular}

\section{A. Multiple Linear Regression Analysis Test Results}

The multiple linear regression model testing in this study uses three independent variables, namely financial technology, company characteristics, and owner characteristics and one dependent variable, namely the financial decision. Table 1 presents the results of the SPSS multiple linear regression analysis for this research model.

Table 1. Multiple Linear Regression Analysis Test Results

Primary Data, 2020

The unstandardized coefficients from the results of the multiple linear regression test in Table 1 can form the regression equation in this study as follows.

$$
\mathrm{Y}=-0.822+0.392(\mathrm{X} 1)+0.263(\mathrm{X} 2)+0.271(\mathrm{X} 3)
$$

\section{B. Simultaneous testing ( $F$ test)}

This publication is licensed under Creative Commons Attribution CC BY.

http://dx.doi.org/10.29322/IJSRP.10.11.2020.p10773

WwW.ijsrp.org 
The $\mathrm{F}$ test is conducted to determine the effect and significance of all independent variables on the dependent variable simultaneously (simultaneously). The results of the $\mathrm{F}$ test which states the significance of $\mathrm{F}$ or probabilities value $<0.05$, the relationship between the independent variables is a significant influence on MSME financial decisions in Bali Province and the model used in this study is said to be feasible. The results of the $\mathrm{F}$ test are presented in Table 2 as follows:

Table 2. F Test

\begin{tabular}{lllllll}
\hline & Model & Sum of Squares & df & Mean Square & F & Sig. \\
\hline \multirow{3}{*}{1} & Regression & 25,626 & 3 & 8,542 & 13,649 & $0,000^{\mathrm{b}}$ \\
& Residual & 60,080 & 96 & 0,626 & & \\
& Total & 85,706 & 99 & & & \\
\hline
\end{tabular}

Primary Data, 2020

Based on Table 2, it can be seen that the significance value of the $\mathrm{F}$ test is 0,000 , which means that it is smaller than 0.05 , the $\mathrm{F}$ test hypothesis is accepted, namely financial technology (X1), company characteristics (X2), and owner characteristics (X3) simultaneously or simultaneously have an effect on the financial decision (Y) of MSMES in Bali Province and the model used in this study is said to be feasible.

\section{C. $\quad$ Partial testing ( $t$ test)}

The $t$ test is performed to show the effect and significance of each independent variable on the dependent variable or partial testing. The partial influence of financial technology, company characteristics and owner characteristics on MSME financial decisions in Bali Province can be seen through the significance value or probability value of $5 \%$ or 0.05 . Conclusion drawing is done with the criteria if the significance value is $<0.05$ then financial technology, company characteristics, and owner characteristics partially affect the financial decisions of MSMEs in Bali Province (hypothesis is accepted). On the other hand, if the significant value is> 0.05, then financial technology, company characteristics, and owner characteristics do not partially affect MSME financial decisions in Bali Province (hypothesis is rejected). The $t$ test results are shown in Table 3 as follows:

Table 3. $\mathrm{t}$ test

\begin{tabular}{lll}
\hline Variabel & t & Sig. Uji t \\
\hline Financial Technology (X1) & 2,539 & 0,013 \\
Company Characteristics (X2) & 3,805 & 0,000 \\
Owner's Characteristics (X3) & 4,819 & 0,000 \\
\hline
\end{tabular}

Primary Data, 2020

\section{The effect of financial technology on financial decisions (H1)}

Based on the results of the analysis in Table 3, it shows that financial technology has a significance value of 0.013 , which is smaller than 0.05 , so that the hypothesis can be accepted. Therefore it can be concluded that there is an influence of financial technology on MSME financial decisions in Bali Province. This means that the development and existence of this Fintech lending can be reached as an alternative financial for MSMEs in provinces that have difficulties in accessing finance.

This study found that financial technology has a positive effect on MSME financial decisions in Bali Province. The results of this study indicate that financial technology, which is measured by the use of Fintech lending indicators, offers lower transaction costs, which is an alternative source of financial for MSMEs in Bali Province. This means that the transaction fees offered by Fintech lending make it more accessible to the MSME sector in Bali Province as an alternative source of financial.

The development of Fintech lending in Bali can certainly be a solution to the financial problems experienced by MSMEs so far. The existence of this fintech lending can reach and become a bridge for MSMEs in Bali in obtaining financial sources for the sustainability of their business. The results of this study are also supported by research conducted by Ardiansyah (2019), Huang (2019) and Ghazali (2018) which states that there is a positive effect of Fintech lending on MSME financial decisions

\section{E. The Effect of company characteristics on financial decisions (H2)}

Based on the results of the analysis in Table 3, it shows that the characteristics of the company have a significance value of 0.000 , which means it is smaller than 0.05 , so the hypothesis is accepted. It can be concluded that there is an influence of company characteristics on 
MSME financial decisions in Bali Province. This means that the characteristics of MSMEs determine the decision to use the source of funds used in running their business.

This study found that company characteristics have a positive effect on MSME financial decisions in Bali Province. The results of this study indicate that the characteristics of the company as measured by the size indicator of MSMEs, namely based on the number of employees or workers, affect the financial decisions for MSMEs in Bali Province. The size of the MSMEs that is getting bigger increases the decision to finance MSMEs in Bali to use more debt. The larger size of MSMEs as measured by the number of employees makes MSMEs have higher work productivity in producing products, thus requiring large financial to finance them. The limited capital owned by MSMEs makes debt an alternative source of financial.

The influence of company characteristics on financial decisions means that the larger the company size, the higher the use of external sources of funds. When the company grows, the higher the need for its use of funds. The results of this study are also supported by research conducted by Zunckel (2019), Fachrudin (2018), (Wasiuzzaman \& Nurdin (2019) and Prastikaa (2019) which states that there is a positive influence on company characteristics on MSME financial decisions

\section{F. The Effect of owner characteristics on financial decisions (H3)}

The results of the analysis in Table 3 show that the characteristics of the owner have a significance value of 0.000 , which means less than 0.05 , so the hypothesis is accepted. Thus it can be concluded that there is an effect of owner characteristics on MSME financial decisions in Bali Province. This means that MSMES owners have an important role in determining or making decisions regarding the use of sources of funds in running their business.

This study found that owner characteristics have a positive effect on MSME financial decisions in Bali Province. This study shows that the owner characteristics as measured by the owner's education level indicator influence the MSME financial decisions in Bali Province. MSME owners who have higher education can increase their financial decisions using more debt. Higher education for MSME owners shows increased insight in innovating both in product, process and marketing innovations so that it requires large financial. The limited capital owned by MSMEs makes financial originating from debt an alternative.

The effect of owner characteristics on financial decisions, meaning that the higher the level of education of business owners, the greater the opportunity to access financial. The higher level of education of the business owner provides greater confidence in dealing with external parties when making financial requests. This education affects the owner's attitude in making financial decisions. The owner's high education level tends to have a better ability in doing financial planning. The results of this study are also supported by research conducted by Rasheed (2018), Kuruppu \& Azeez (2016) and Rossi et al. (2016) which states that there is a positive influence on owner characteristics on MSME financial decisions

\section{G. Determination Coefficient Testing $\left(R^{2}\right)$}

The coefficient of determination measures the extent to which the variance of the independent variable is able to explain the variance of the dependent variable. In this study, the coefficient of determination is indicated by the adjusted $\mathrm{R}$ square value. The results of the coefficient of determination test can be shown in Table 4 below:

Table 4. Determination Coefficient Testing $\left(\mathbf{R}^{2}\right)$

\begin{tabular}{lllll}
\hline Model & R & R Square & Adjusted R Square & Std. Error of the Estimate \\
\hline 1 & $0,547^{\text {a }}$ & 0,299 & 0,277 & 0,79110 \\
\hline
\end{tabular}

Primary Data, 2020

Based on Table 4, it can be seen that the adjusted $\mathrm{R}$ square value of this study is 0.277 or 27.7 percent. This value means that 27.7 percent of the variance of MSME financial decisions in Bali Province can be explained or influenced by financial technology, company characteristics, and owner characteristics. The remaining 72.3 percent is explained or influenced by other variables not explained in this study.

\section{CONCLUSION}

Theoretically, this research can provide scientific contributions and empirical evidence that financial decisions are influenced by technological developments in digital financial services called financial technology, company characteristics and company owner characteristics. This study found that financial technology, company characteristics, and owner characteristics had a positive effect on financial decisions Based on these findings, this research has practical implications that financial technology, company characteristics,

This publication is licensed under Creative Commons Attribution CC BY.

http://dx.doi.org/10.29322/IJSRP.10.11.2020.p10773

WwW.ijsrp.org 
and owner characteristics can be taken into consideration in making financial decisions by the MSME sector in Bali Province. For MSMEs in Bali Province, the results of this study are expected to increase the ability to use technology in the field of digital-based financial services such as financial technology, so that it can help in business processes. 
The existence of limited time and conditions, this study is limited to only taking 100 samples from the total population of MSMEs in Bali Province. Further researchers are advised to use a larger sample so that they can represent more of the MSME population in Bali Province.

\section{REFERENCES}

[1] Ahad. (2017). OJK : Fintech Bisa Selamatkan MSMES dari Masalah Modal. Diambil 26 Juli 2020, dari Republika website: m.republika.co.id

[2] Ardiansyah, T. (2019). Model Financial Dan Teknologi (Fintech) Membantu Permasalahan Modal Wirausaha MSMES Di Indonesia. Majalah Ilmiah Bijak, 16(2), 158-166. https://doi.org/10.31334/bijak.v16i2.518

[3] Avery, R. B. et al. (1998). The role of personal wealth in small business finance. Journal of Banking and Finance, 22(6-8), 1019-1061. https://doi.org/10.1016/S0378-4266(98)00016-8

[4] Bank Indonesia. (2017a). Kajian Stabilitas Keuangan Bank Indonesia. Indonesia.

[5] Blackburn, R. A. et al. (2013). Small business performance : business, strategy and owner-manager characteristics. Journal of Small Business and Enterprise Development, 8-27. https://doi.org/10.1108/14626001311298394

[6] Briozzo, A., Vigier, H., \& Martinez, L. B. (2016). Firm-Level Determinants of the Financing Decisions of Small and Medium Enterprises: Evidence from Argentina. Latin American Business Review, 17(3), 245-268. https://doi.org/10.1080/10978526.2016.1209081

[7] Ciarán mac an Bhaird, B. M. L. (2010). Determinants of capital structure in Irish SMEs. Small Business Economics, 35(3), 357-375. https://doi.org/10.1007/s11187-008-9162-6

[8] Coleman, S. (2000). Access to capital and terms of credit: A comparison of men-and women-owned small businesses. Journal of Small Business Management, 38(3), 37-52.

[9] Fachrudin, K. A. (2018). Determinan Preferensi Struktur Modal Usaha Mikro dan Kecil. Ekuitas: Jurnal Ekonomi dan Keuangan, (80), 318-336

[10] Fahmi, I. (2018). Pengantar Manajemen Keuangan. Bandung: Alfabeta.

[11] Fairlie, R. W., \& Robb, A. M. (2009). Gender differences in business performance: Evidence from the characteristics of business owners survey. Small Business Economics, 33(4), 375-395. https://doi.org/10.1007/s11187-009-9207-5

[12] Gibilaro, L., \& Mattarocci, G. (2018). Peer-to-peer lending and real estate mortgages: evidence from United Kingdom. Journal of European Real Estate Research, 11(3), 319-334. https://doi.org/10.1108/JERER-12-2016-0048

[13] Hakim Ghazali, N. (2018). Awareness and Perception Analysis of Small Medium Enterprise and Start-up Towards FinTech Instruments: Crowdfinancial and Peer-to-Peer Lending in Malaysia. International Journal of Finance and Banking Research, 4(1), 13. https://doi.org/10.11648/j.ijfbr.20180401.12

[14] Huang, B. (2020). A Research on the Influence of Digital Inclusive Finance on Financing Constraints of SMEs. International Conference on Economic Management and Cultural Industry (ICEMCI 2019), 109(Icemci), 545-550. https://doi.org/10.2991/aebmr.k.191217.098

[15] Husnan, S. dan E. P. (2015). Dasar-Dasar Manajemen Keuangan (Ketujuh). Yogyakarta: UPP STIM YKPN.

[16] Internasional Pricewaterhouse Coopers. (2019). Survei PwC: 74\% MSMES Belum Dapat Akses Pembiayaan Akses Pembiayaan MSMES. Diambil 14 Maret 2020, dari Katadata website: https://www.pwc.com/id/en/media-centre/pwc-in-news/2019/indonesian/survei-pwc-74-MSMEs.html

[17] Kuruppu, G., \& Azeez, A. A. (2016). Financing preferences of small and medium enterprise owners of Sri Lanka : Does pecking order theory hold? Journal of Business \& Economic Policy, 3(2), 79-92.

[18] Nugroho, A. (2010). Analisis Pengaruh Karakteristik Demografi dan Faktor Ekonomi Terhadap Pemilihan Sumber Pendanaan Usaha Angkutan Kota Salatiga. FE UKSW.

[19] Ogubazghi, S. K., \& Muturi, W. (2014). The Effect of Age and Educational Level of Owner/Managers on SMMEs' Access to Bank Loan in Eritrea: Evidence from Asmara City. American Journal of Industrial and Business Management, 04(11), 632-643. https://doi.org/10.4236/ajibm.2014.411069

[20] Osei-Assibey, E. et al. (2012). Microenterprise financing preference: Testing POH within the context of Ghana's rural financial market. Journal of Economic Studies, 39(1), 84-105. https://doi.org/10.1108/01443581211192125

[21] Otoritas Jasa Keuangan. (2016). POJK No. 77/POJK.01/2016 tentang Layanan Pinjam Meminjam Uang Berbasis Teknologi Informasi. Indonesia.

[22] Otoritas Jasa Keuangan. (2020). Statistik Perkembangan Fintech Lending. Diambil dari ojk.go.id

[23] Prastikaa, C. D. \& D. (2019). Pengaruh Struktur Aktiva Dan Profitabilitas Terhadap Struktur Modal (Penelitian Pada Pt. Mayora Indah, Tbk.). 5(Mei), 5159.

[24] Rasheed, R. (2018). Attitude for inclusive finance : influence of owner-managers ' and firms ' characteristics on SMEs financial decision making. Journal of Economic and Administrative Sciences. https://doi.org/10.1108/JEAS-05-2018-0057

[25] Rio, M. (2018). Potret Pendanaan MSMES Berdasarkan Siklus Hidup Usaha Portrait of MSMES Financial Based on the Business Life Cycle. Jurrnal EBBANK, 9(2), 27-34.

[26] Rizal, M. (2018). Fintech As One Of The Financing Solutions For SMEs. Jurnal Pemikiran dan Penelitian Administrasi Bisnis dan Kewirausahaan, 3(2), $89-100$.

[27] Robb, A., \& Wolken, J. D. (2005). Firm, Owner, and Financing Characteristics: Differences between Female- and Male-owned Small Businesses. SSRN Electronic Journal, (March). https://doi.org/10.2139/ssrn.306800

[28] Rossi, M. et al. (2016). The impact of corporate characteristics on the financial decisions of companies: evidence on financial decisions by Italian SMEs. Journal of Innovation and Entrepreneurship, 5(1). https://doi.org/10.1186/s13731-015-0031-7

[29] Sartono, A. (2016). Manajemen Keuangan Teori dan Aplikasi. In BPFE (4 ed.). Yogyakarta.

[30] Sybirianska, Y. et al. (2018). Fintech platforms in sme's financing: eu experience and ways of their application in Ukraine. Investment Management and Financial Innovations, 15(3), 83-96. https://doi.org/10.21511/imfi.15(3).2018.07

[31] Urba, N. et al. (2019). Pendapatan dan Laba Bersih Sebelum dan Sesudah Pendanaan di Financial Teghnology: Studi MSMES Kota Palembang. Mbia, 18(3), 114-120. https://doi.org/10.33557/mbia.v18i3.680

[32] Wasiuzzaman, S., \& Nurdin, N. (2019). Debt financing decisions of SMEs in emerging markets: empirical evidence from Malaysia. International Journal of Bank Marketing, 37(1), 258-277. https://doi.org/10.1108/IJBM-12-2017-0263

[33] Welmilla, I. et al. (2011). The impact of demographic factors of entrepreneurs on development of SMEs in tourism industry in Sri Lanka. Faculty of Commerce and Management Studies, University of Kelaniya, Sri Lanka.

[34] Wiagustini, N. L. P. (2014). Dasar-Dasar Manajemen Keuangan (Pertama; J. Atmaja, Ed.). Indonesia: Udayana University Press.

[35] Xiang, D. et al. (2018). Determinants of the Use of Fintech Finance among Chinese Small and Medium-Sized Enterprises. TEMS-ISIE 2018 - 1st Annual International Symposium on Innovation and Entrepreneurship of the IEEE Technology and Engineering Management Society, 1-10. https://doi.org/10.1109/TEMS-ISIE.2018.8478470

[36] Yuan et al. (2019). Small and medium size enterprises (SMES ) in Malaysia: A conceptual underpinning of capital structure. European Journal of Social Sciences Studies, 4(5), 219-233. https://doi.org/10.5281/zenodo.3598144

This publication is licensed under Creative Commons Attribution CC BY.

http://dx.doi.org/10.29322/IJSRP.10.11.2020.p10773

WwW.ijsrp.org 
[37] Zunckel, S. (2019). Capital structure of small, medium and micro enterprises: major factors for a developing economy. Problems and Perspectives in Management, Vol. 17, hal. 124-133. https://doi.org/10.1007/s11187-007-9088-4

This publication is licensed under Creative Commons Attribution CC BY. 